\title{
Covid-19: India imposes lockdown for 21 days and cases rise
}

\author{
Priyanka Pulla
}

Bangalore

The Indian government has announced a countrywide lockdown for three weeks starting at midnight on 24 March to slow the spread of covid-19 as the number of people testing positive in the country reached 563 .

Although most of these people had contact with travellers returning from countries affected by covid-19, a few had no such link, suggesting that community transmission may have begun in some Indian states.

Prime minister Narendra Modi announced that all government offices would be shut for 21 days, except essential services such as the fire service, police, and hospitals.

Several experts have welcomed the move, although it could result in food shortages and hurt those in the unorganised workforce.

Gagandeep Kang, executive director of Faridabad's Translational Health Sciences and Technology Institute, wrote on Twitter that the lockdown was the "right move, just in time." But she cautioned that it wouldn't contain covid-19, but would buy some time, during which India needed to make a greater effort to detect cases and isolate patients.

Since India reported its first covid-19 positive patient on 31 January, the government has gradually been widening measures to prevent international passengers from importing the virus into the country.

On 2 March travellers from four countries were asked to quarantine themselves and this list was expanded on 15 March when most visas to India were suspended. But these measures were hard to enforce, with many reports of people flouting them. One doctor, who had recently returned to Rajasthan from Saudi Arabia, reportedly hid his travel history and treated numerous patients. He later tested positive for covid-19 along with five of his colleagues.

The transmission of covid-19 by asymptomatic people could also reduce the effectiveness of airport screening and quarantine measures. In a paper ${ }^{1}$, scientists from the Indian Council of Medical Research estimated that, compared with a scenario that had no airport screening, the identification of all symptomatic cases via airport screening would only delay an epidemic (defined as 1000 cases countrywide) by a maximum of three days. It suggested that to delay an epidemic appreciably, India would need to test symptomatic people with no travel history as well.
Contrary to what the paper recommended, however, the Indian government began testing all people with severe pneumonia but no travel history only last week.

Another major hurdle that India faces in containing covid-19 is the spread of the virus among economically disadvantaged people, who may not be able to isolate themselves. Last week, a 68 year old woman based in Mumbai, who was working as a domestic help, reportedly contracted covid-19 from her employer who had returned from the United States. The Indian Express wrote that her family of six lived in a small home in a slum of more than 23000 people. $^{2}$ The closely packed home, and the fact that she routinely used a public washroom, made contact tracing difficult for public health officials.

Even government measures to mitigate covid-19 have led to precarious situations that could heighten transmission. For example, when a few states imposed lockdowns last week, large numbers of migrant workers from sectors such as construction and tanneries found themselves without jobs, and they returned to their hometowns on crowded trains and buses.

Many of these workers are now in state run shelters after the announcement of the India lockdown and the suspension of trains, planes, and buses across the country.

Meanwhile, the trajectory of covid-19 in India seems poised to change gears. Although the number of cases rose slowly in February, in mid March they doubled from 100 to more than 236 in just five days. According to an analysis published on 22 March by the COV-IND-19 Study Group, a team of epidemiologists based in the US, India could see between around 100000 and 1.3 million confirmed cases of covid-19 by the middle of May if the virus continues to spread at its current rate.

The authors suggested that the government consider a universal basic income for poor and vulnerable people who are affected by lockdowns. So far, only a few Indian states including Kerala, Uttar Pradesh, Haryana, and Punjab have announced financial assistance to daily wage workers.

1 Mandal S, Bhatnagar T, Arinaminpathy N, etal . Prudent public health intervention strategies to control the coronavirus disease 2019 transmission in India: A mathematical model-based approach. Indian J Med Res 2020;151. 10.4103/ijmr. IJMR 504 20.

2 Barnagarwala T. Case in a Mumbai slum: Officials hit tracking hurdle. MSN News. 21 March 2020 https://www.msn.com/en-in/news/other/case-in-a-mumbai-slum-officials-hittracking-hurdle/ar-BB11tK6Y

Published by the BMJ Publishing Group Limited. For permission to use (where not already granted under a licence) please go to http://group.bmj.com/group/rights-licensing/ permissions 